\title{
Features of the morphological and anatomical characteristics of the leaves of Taraxacum officinale Wigg. in conditions of rock dump
}

\author{
O.M. Legoshchina ${ }^{1}$, I.N. Egorova ${ }^{1}$, O.A. Neverova ${ }^{2}$, A.A. Bykov ${ }^{3}$, E.M. Maltseva ${ }^{4}$, V.V. Bolshakov ${ }^{4}$ \\ ${ }^{1}$ Federal Research Center for Coal and Coal Chemistry Siberian Branch of the Russian Academy of Sciences, Institute of Human \\ Ecology, Kemerovo, Russia \\ ${ }^{2}$ Kemerovo State University, Kemerovo, Russia \\ ${ }^{3}$ Institute of Computational Technologies Siberian Branch of the Russian Academy of Sciences, Kemerovo, Russia \\ ${ }^{4}$ Kemerovo State Medical University, Kemerovo, Russia \\ E-mail: legolia2012@yandex.ru
}

Received: 22.08.2019. Accepted: 22.07.2019

\begin{abstract}
The morphological and anatomical features of the assimilation apparatus Taraxacum officinale Wigg., growing under the conditions of a rock dump of the Kedrovsky coal mine in the Kemerovo Region, were studied. It was experimentally established that the specific environmental conditions of the rock dump cause morphological and anatomical changes in the leaves of the dandelion. At the level of leaf morphology, there is a decrease in the average leaf area, thickening of leaf blades, the formation of a trend towards a decrease in the number of leaves in the outlet. At the level of the anatomical structure, there is a significant increase in the thickness of mesophyll, a tendency to a decrease in the thickness of the tissues of the upper and lower epidermis, a decrease in the number of cells of the upper and lower epidermis by $1 \mathrm{~mm}^{2}$ and an increase in the size of stomata in the tissues of the lower and upper epidermis, a decrease in the number of stomata by $1 \mathrm{~mm}^{2}$ and stomatal index on the upper epidermis. Under the conditions of the rock dump, an increase in the number of reliable correlations between the anatomical parameters of the leaf of Taraxacum officinale Wigg., as well as anatomical signs with indicators of atmospheric pollution, was established, to a greater extent due to the formation of positive correlations that are known to control the development of biosystems and are critical for body periods.
\end{abstract}

Keywords: Morphology; Anatomy; Leaf; Dandelion officinalis; Environmental Conditions; Rock Dumps; Opencast coal mine

\section{Introduction}

As a result of coal mining in Kuzbass, the area of disturbed lands exceeds 100 thousand hectares. Along with reclamation, man-made soils are naturally overgrown as a result of seed drift from the surrounding territories. Rock dumps formed as a result of an open coal mining method are characterized by specific environmental conditions-topography, formation of borrow cut, depression funnels, environmental pollution by chemical elements and their compounds, especially air slack. The technogenic change of the relief on the waste dumps leads to a lack of productive moisture, failure of water permeability, contrasting temperature conditions on different elements of the relief; low potential fertility of embryozems (Manakov, 2012). In this regard, waste dumps are a classic object for studying the adaptive mechanisms of plants settling on them. A high degree of resistance of some species of higher plants is ensured by a combination of morphological, physiological, anatomical adaptive reactions, which makes these plants potentially capable of improving the quality of the natural environment-urban areas, industrial zones, and man-made disturbed soils. Plant adaptations are associated, first of all, with rearrangements of their assimilating organs, which, due to their gas exchange function, are highly sensitive to external influences (Neverova et al., 2013). It is known that morphological and anatomical rearrangements alter the physiological status of a plant under extreme conditions of existence for a more efficient use of environmental resources (Menshakova et al., 2008). The aim of the work is to study the morphological and anatomical features of the assimilation apparatus Taraxacum officinale Wigg., growing in the conditions of the rock dump of the Kedrovsky opencast coal mine.

\section{Materials and methods}

The studies were carried out at the Yuzhniy rock dump of the Kedrovsky opencast coal mine. The spoil hear has a flat-sloping relief with a height of $58 \mathrm{~m}$, an area of 599.3 hectares. The dump rocks are represented by sandstone (60\%), siltstones (20\%), mudstones (15\%), loams and clays (5\%) (Figure 1). The experimental site is located at the top of the planned refuse dump. The duration of the biocenosis is $7-10$ years. The technical and biological stages of soil reclamation were carried out at the dump (planting Pinus sylvestris L. and Onobrychis arenaria (Kit.) DC., the initial stages of the formation of meadow communities are observed, there are separate sections of rocky placers with an area of up to $3 \mathrm{~m}^{2}$ from a different format of the dump rock, completely devoid of vegetation. Foliage cover is up to $50 \%$, in rocky areas less than $10 \%$. There is no turfness. Onobrychis arenaria (Kit.) DC., Taraxacum officinale Wigg, Melilotus officinalis (L.) Pall., Artemisia sericea Web. Ex Stechm., Picris hieracioides L. are prevailing in the grass. Embryozems are characterized by alkaline reaction ( $\mathrm{pH}$ of water extract 7.1-7.7), average availability of humus (3.5\%), low availability of mobile forms of phosphorus $(10-50 \mathrm{~m} / \mathrm{kg})$ and nitrogen $(3.6-6.0 \mathrm{mg} / \mathrm{kg})$, high availability of potassium $(100-140 \mathrm{mg} / \mathrm{kg})$, lack of productive moisture $(19-22 \mathrm{~mm}$ in the $0-20 \mathrm{~cm}$ layer). The control site was located $15 \mathrm{~km}$ north-west from the spoil hears on the border of the birch forest. A large area (about 80\%) of the plot is occupied by a gramineous-herb meadow. The projective cover is 95-100\%, the soil is not sod. Centaurea scabiosa L., Hieracium umbellatum L., Lathyrus pratensis L., Achillea Asiatica Serg., Taraxacum officinale Wigg. predominate in meadow communities. The soils of the site are represented by chernozem-meadow medium-thick heavy loam with a high supply of humus $(9.65 \%)$, a relatively high content of phosphorus $(83.0 \mathrm{mg} / \mathrm{kg})$ and potassium $(171.0 \mathrm{~m} / \mathrm{kg})$, a slightly acidic soil solution $(\mathrm{pH} 6,1$ ... 6.3) and a good supply of productive moisture $(50-60 \mathrm{~mm}$ in a $0-20 \mathrm{~cm}$ layer). 


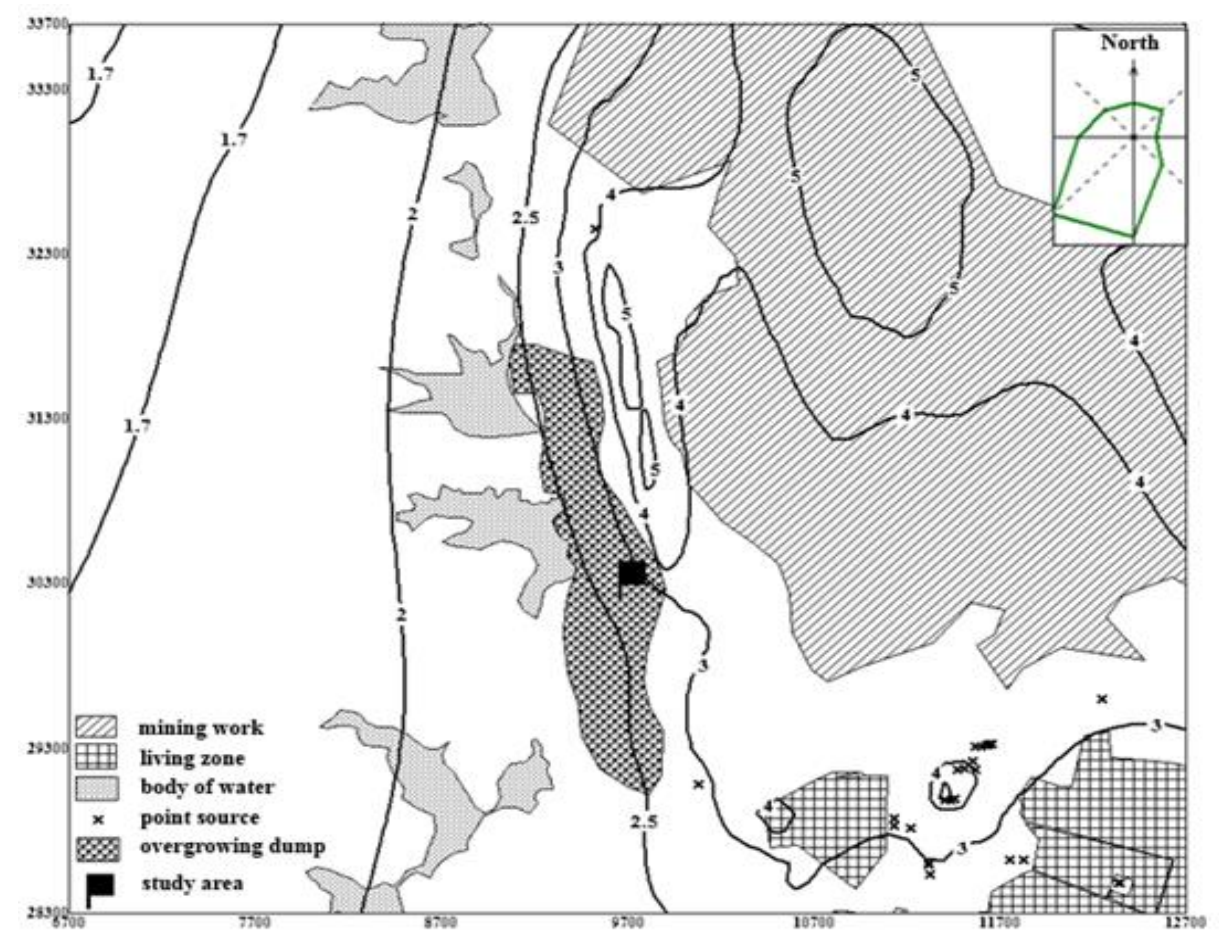

Figure 1. Surroundings of the research site with isolines of the calculated comprehensive indicator of average annual air pollution.

To calculate the impact of industrial emissions into the atmosphere on vegetation in the research area, the ERA-AIR software package (http: //www.lpp.ru) was used, which implements the normative models for calculating maximum single and average annual concentrations adopted in Russia from 01.01.2018 and given in the order (Order of the Ministry of Natural Resources of Russia of 06.06.2017 No. 273). The models make it possible to calculate the single and average annual atmospheric pollution by both gaseous and precipitating emissions of impurities from industrial sources from data on emissions of sources of atmospheric pollution and characteristic meteorological parameters for a given territory. Obviously, the condition of plants depends primarily on the long-term effects of pollutants, which is determined by the average annual concentrations in the surface layer of the atmosphere and the annual fall of aerosols on the soil cover. The module for calculating the precipitation of particles on the underlying surface (Bykov et al., 2002), which is a research supplement to the ERA-AIR SC, was repeatedly used in the Kuzbass conditions and showed good agreement between the calculation results and field observations (Bykov et al., 2006).

The composition of the initial data for calculating the average concentration over a long period of time, in addition to source parameters, includes three distribution densities: wind direction $\mathrm{p} 1(\varphi)$; wind speed $\mathrm{p} 2(u)$; dimensionless parameter $\lambda$ of turbulent mixing intensity $\mathrm{p} 3(\lambda)$. For normative calculations, these distributions, which determine the long-term atmospheric pollution regime for the study area, are requested from the Main State Hydrometeorological Observatory n.a. A.I. Voeykova (St. Petersburg, Russia). The function p1 $(\varphi)$ (smoothed wind rose) for a specific averaging period can be obtained from the $8^{\text {th }}$ wind rose compiled from standard meteorological observations. However, to assess the effect of pollutants on plants for a long time, it is preferable to use a climatic (average of at least 5 years) wind rose, which is contained in a special meteorological file sent from the Main State Hydrometeorological Observatory.

The research area is affected by sources of air pollution not only from the Kedrovsky opencast coal mine, but also from the cities of Kemerovo, powerful sources of energy and chemical enterprises located in the southwest $20 \mathrm{~km}$ from the experimental site, i.e. from the direction of the prevailing winds. The parameters of the sources of atmospheric pollution of urban enterprises and roads are taken from the inventory materials of the consolidated volume of MPE of the city of Kemerovo, and the Kedrovsky open pit sources based on departmental volume of MPE, developed a little later.

In the process of modeling atmospheric pollution, the conditional dimensionless complex indicator (CI) of the total average annual atmospheric pollution $\mathrm{Cl}=\mathrm{C} 1 / \mathrm{MPC}_{\mathrm{c} 1}+\mathrm{C} 2 / \mathrm{MPC}_{\mathrm{c} 2}+\ldots . . .+\mathrm{Cn} / \mathrm{MPC}_{\mathrm{cn}}$, where $\mathrm{C}_{\mathrm{i}}, \mathrm{i}=1,2, \ldots, \mathrm{n}$, was calculated total annual average surface concentration of impurities over all sources, $\mathrm{MPC}_{\mathrm{ci}}$ corresponding average daily hygienic $\mathrm{MPC}_{\mathrm{s}}$, and indices $1,2, \ldots, \mathrm{n}$ relate to pollutants whose average annual $\mathrm{Ci}$ concentrations exceed the level of $0.1 \mathrm{MPC}$. When calculating the $\mathrm{Cl}$, the following substances and their compounds were taken into account: manganese and its compounds, lead and its inorganic compounds, nitrogen dioxide, nitrogen oxide, sulfuric acid, soot, sulfur dioxide, hydrogen sulfide, carbon oxide, gaseous fluoride compounds, chlorine, ammonium carbonate, benzene, dimethylbenzene, methylbenzene, benz(a)pyrene, naphthalene, butan-1-ol, cyclohexanol, butyl acetate, formaldehyde, cyclohexanol, dimethylaniline, nitrobenzene, kerosene, petroleum-based mineral oil, hydrocarbons saturated $\mathrm{C} 12-\mathrm{C} 19$, inorganic dust containing silicic acid anhydride, abrasive dust, coal dust. This indicator is not a normative hygienic criterion, since not all the substances considered have the effect of unidirectional effects on humans. It bears the meaning of the "total manmade load» created by industry through the atmospheric transfer of pollution to a particular territory of the city. Table 1 shows the atmospheric emissions at the observation site.

When calculating the estimation of soil pollution by atmospheric precipitation, the dispersed composition of emissions and the deposition rate of various particle size fractions were additionally set as was done in Modeling of soil pollution by atmospheric emissions from industrial facilities in a coal-mining region (Bykov et al., 2006). The term dust in Table 1 means the sum of all the solid particles emitted into the atmosphere of the city of Kemerovo and the Kedrovsky open pit.

An analysis of the calculated atmospheric emissions in the study area shows that the contribution of the Kedrovsky section to the amount of dust loss dust fall, which is $5.68 \mathrm{~g} / \mathrm{m}^{2}$ per year or $84 \%$ of the total dust loss to the study area, taking into account urban industrial facilities, is most significant. The contribution of the strip mine to the value of the complex indicator of air pollution in the research area is $49.8 \%$ (the 
contribution of the city is $50.2 \%)$. The contribution of the Kedrovsky coal pit to the total amount of precipitation of nitrates and sulfates to the study area is less significant and makes $36 \%$ and $16 \%$, respectively, while the contribution of the city is 64 and $84 \%$, respectively.

The object of botanical research was the medicinal dandelion (Taraxacum officinale Wigg.), as the most common species of perennial herb growing on rock dumps. Harvesting of raw materials was carried out in dry sunny weather, in accordance with generally accepted rules during the period of maximum development of the vegetative mass (end of May 2016). Raw materials were collected without visible signs of damage from 15 accounting sites of $1 \mathrm{~m}^{2}$ in size from the experimental and control plots. For morphological studies, the sample of plants from each accounting site was 10 plants, in total from the experimental and control plots - 150 plants. Leaf area (S) was determined by scanning them with subsequent image processing using the Image Tools computer program. For anatomical studies, plant material was fixed in a $60 \%$ solution of ethyl alcohol. Cross sections were made on the microtome from the middle part of the leaf blade and placed in glycerin. The anatomical parameters of the leaves (the thickness of the sheet and its tissues, the number of cells in $1 \mathrm{~mm}^{2}$ of the lower and upper epidermis, stomata sizes) were measured using an Axioscope-2+microscope, model ZEISSN HBO103 and N XBO75 (Germany) with an ocular micrometer, camera, and software. The stomatal index was calculated by the formula: Si=Nstom $\times 100 \% /(N s t o m+N c e)$, where Nstom is the number of stomata per 1 $\mathrm{mm}^{2}$, Nce is the number of main cells of the leaf epidermis per $1 \mathrm{~mm}^{2}$

Table 1. Indicators of the long-term impact of atmospheric emissions on the study area.

\begin{tabular}{llll}
\hline & Total & $\begin{array}{l}\text { Contribution } \\
\text { of coal mine }\end{array}$ & $\begin{array}{l}\text { Contribution } \\
\text { of the city }\end{array}$ \\
integer $/ \%$ & $2.78 / 100$ & $1.38 / 49.8$ & $1.40 / 50.2$ \\
Dust fallout, $\mathrm{g} / \mathrm{m}^{2}$ per year $/ \%$ & $6.79 / 100$ & $5.68 / 84$ & $1.11 / 16$ \\
Nitrate fallout, $\mathrm{g} / \mathrm{m}^{2}$ per year/\% & $0.31 / 100$ & $0.11 / 36$ & $0.20 / 64$ \\
Sulfates fallout, $\mathrm{g} / \mathrm{m}^{2}$ per year $/ \%$ & $0.16 / 100$ & $0.03 / 16$ & $0.13 / 84$ \\
\hline
\end{tabular}

\section{Results and discussion}

A comparative analysis of the morphology of dandelion growing under various environmental conditions showed that the average leaf area on waste dumps in plants decreases (by 24\%), the number of leaves in the outlet decreases, the leaf blade thickens (by 15\%) (Table 2 and Figure 2 ).

\begin{tabular}{lll}
\hline Indicators & Control & Experience \\
Leaf area, $\mathrm{cm}^{2}$ & $48.02 \pm 4.82$ & $36.43 \pm 3.46^{*}$ \\
Number of leaves on one plant, piece & $5.80 \pm 0.45$ & $4.92 \pm 0.42$ \\
Leaf thickness, $\mu \mathrm{m}$ & $118.10 \pm 3.22$ & $136.25 \pm 6.22^{*}$ \\
Tissue thickness, $\mu \mathrm{m}$ & & \\
- Upper epidermis & $19.61 \pm 1.24$ & $18.66 \pm 1.19$ \\
- Lower epidermis & $16.81 \pm 0.65$ & $15.37 \pm 0.42$ \\
- Mesophyll & $84.00 \pm 2.12$ & $103.11 \pm 3.24^{*}$ \\
Number of mesophyll layers, piece & $4-6$ & $4-6$ \\
\hline
\end{tabular}

Table 2. Anatomical and morphological characteristics of the leaf blade Taraxacum officinale Wigg.

Note: * - significant differences from the control when $p<0.05$.

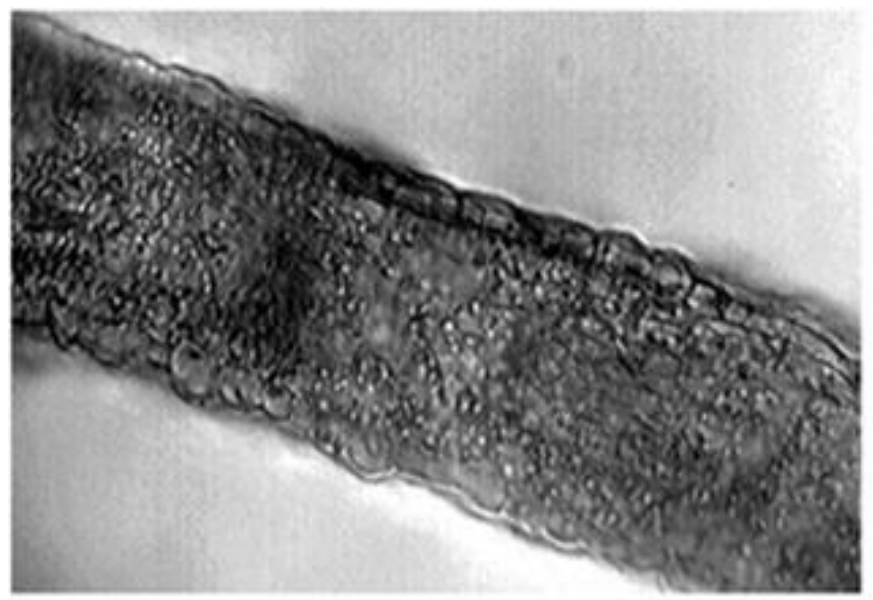

A

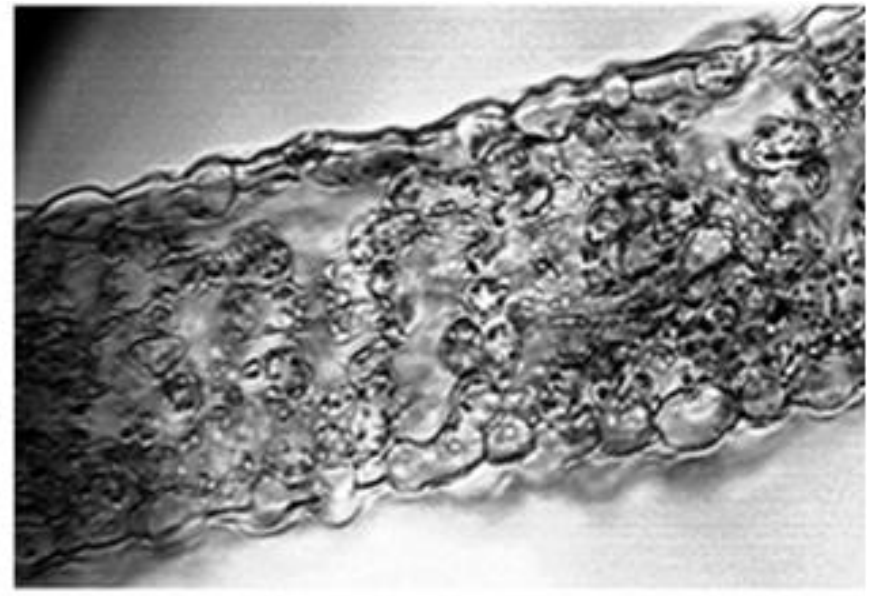

B

Figure 2. Cross cut leaf Taraxacum officinale Wigg. (A - Control, B - Experience).

An analysis of the anatomical structure of the leaves showed that under the conditions of a rock dump, dandelion significantly increases the thickness of mesophyll (by 55\%), there is a tendency to a decrease in the thickness of the tissues of the upper and lower epidermis (Table 2). From literary sources it is known that morphological changes in the leaf are a functional response to environmental factors (Zhongqiang \& Dan, 2009; Scheepens et al., 2010). As noted earlier, waste dumps are characterized by a lack of productive moisture. It is known that when growing under arid conditions and high insolation in herbaceous plants, an increase in the thickness of the leaf plate and assimilation tissue occurs (Ivanova, 2014). P.E. Lauri et al., 2014 found that the lack of moisture leads to a decrease in the area of the leaf blade and it's mass in absolute values, which can be considered as an adaptive reaction to adverse environmental factors. It is known that adaptive reactions of plants to 

environmental factors are non-specific. So according to T.G. Akatieva 2014, near the industrial enterprises of Iset district of the Tyumen region, dandelion officinalis showed a decrease in the number of leaves per 1 plant, plant height, leaf length and width. A.K. Frolov 1998 notes in urban conditions an increase in the thickness of the sheet and mesophyll in the dandelion officinalis, a decrease in the size (length and width) of spongy tissue cells. Anatomical and morphological changes towards xeromorphism are observed in lawn grass under conditions of anthropogenic pollution of Yoshkar-Ola: thickening of the leaf blade due to an increase in the height of the epidermis and mesophyll, reduction of the intercellular spaces, decrease in the length and width of the leaf blade (Polovnikova, 2007).

Under the influence of adverse environmental factors, the most obvious responses of plants are manifested in the structure of the leaf epidermis. The obtained experimental data testify to the differences in the anatomical features of the epidermis of the leaf of the dandelion officinalis growing under the conditions of a rock dump (Table 3).

Table 3. Anatomical characteristics of the epidermis of the leaf Taraxacum officinale Wigg.

\begin{tabular}{|c|c|c|c|c|}
\hline \multirow[b]{2}{*}{ Studied parameters } & \multicolumn{2}{|c|}{ Lower epidermis } & \multicolumn{2}{|c|}{ Upper epidermis } \\
\hline & control & experience & control & experience \\
\hline Number of cell in $1 \mathrm{~mm}^{2}$ & $978.80 \pm$ & $924.45 \pm$ & $1042.37 \pm$ & $940.44 \pm$ \\
\hline & 24.32 & 16.23 & 25.62 & 20.08 \\
\hline Number of stomata in $1 \mathrm{~mm}^{2}$ & $142.02 \pm 1.29$ & $125.01 \pm 1.34^{*}$ & $81.01 \pm 1.14$ & $60.02 \pm 0.82 *$ \\
\hline Stomata length, $\mu \mathrm{m}$ & $24.36 \pm 0.47$ & $26.12 \pm 0.58$ & $23.65 \pm 0.52$ & $24.28 \pm 0.46$ \\
\hline Stomata width, $\mu \mathrm{m}$ & $19.32 \pm 0.41$ & $20.54 \pm 0.67$ & $17.93 \pm 0.36$ & $18.44 \pm 0.92$ \\
\hline Stomatal index, \% & $12.67 \pm 0.25$ & $11.87 \pm 0.11$ & $7.21 \pm 0.28$ & $6.21 \pm 0.36^{*}$ \\
\hline
\end{tabular}

Note: * - significant differences from the control when $p<0.05$.

In particular, medicinal dandelion growing on pit tips tends to decrease the number of cells in $1 \mathrm{~mm}^{2}$ and increase the size of stomata in the tissues of the lower and upper epidermis, the number of stomata significantly decreases by $1 \mathrm{~mm}^{2}$ ( 12 and $26 \%$, respectively); on the upper epidermis there is a significant decrease in the stomatal index (by $14 \%$ ). Given the low supply of productive moisture of embryozems on rock dumps, a decrease in the stomatal index is a natural response of plants to survival. There is information in the literature that the low frequency of stomata in combination with their large sizes contributes to a more effective control of water exchange (Ceulemans et al., 1978; Bissing, 1982). Our findings are also consistent with I.I. Krokhmal 2015, who established that in Campanula sibirica L. at the level of rosette leaves, adaptation to radical growing conditions is achieved by reducing the number of stomata and increasing their size.

Based on the correlation analysis, the dependence of the anatomical and morphological characters of the leaves of Taraxacum officinale Wigg. on the indicators of atmospheric emissions in the territory of the waste dump was revealed (Table 4).

The results of the correlation analysis show that the value of the complex indicator of atmospheric pollution $(\mathrm{Cl})$ and dustfall are significantly correlated with some anatomical and morphological characteristics of the leaves of Taraxacum officinale Wigg. In particular, the leaf area, the thickness of the upper and lower epidermis, the number of cells and stomata in $1 \mathrm{~mm}^{2}$ of the lower and upper epidermis negatively correlate with the index of $\mathrm{Cl}$; while positive correlations are formed between the $\mathrm{Cl}$ and such indicators as: sheet thickness, mesophyll thickness, length and width of stomata of the lower and upper epidermis; the number of stomata is $1 \mathrm{~mm}^{2}$ and the stomatal index of the upper epidermis is inversely related to the amount of dust falled. Thus, the experimentally established success rate of the growth of Taraxacum officinale Wigg. in conditions of a rock dump, including a certain correlation of «+» and «-», reliable correlations between the indicators of technogenic pollution of the waste dump and the anatomical and morphological characteristics of the leaves are provided.

Table 4. Significant correlations between the anatomical and morphological features of the leaves of the Taraxacum officinale Wigg. and indicators of the long-term effects of air emissions on the territory of the waste dump.

\section{Depending studied traits}

$\mathrm{Cl}$ - Leaf area

$\mathrm{Cl}$ - Leaf thickness

$\mathrm{Cl}$ - Thickness of the upper epidermis

$\mathrm{Cl}$ - Thickness of the lower epidermis

$\mathrm{Cl}-$ Mesophyll thickness

$\mathrm{Cl}$ - The number of cells in $1 \mathrm{~mm}^{2}$ of the lower epidermis

$\mathrm{Cl}$ - The number of stomata in $1 \mathrm{~mm}^{2}$ of the lower epidermis

$\mathrm{Cl}$ - The length of the stomata of the lower epidermis

$\mathrm{Cl}$ - Stomata width of the lower epidermis

$\mathrm{Cl}$ - The number of cells in $1 \mathrm{~mm}^{2}$ of the upper epidermis

$\mathrm{Cl}$ - The number of stomata in $1 \mathrm{~mm}^{2}$ of the upper epidermis

$\mathrm{Cl}$ - The length of the stomata of the upper epidermis

$\mathrm{Cl}$ - Stomata width of the upper epidermis

Dust fallout - The number of stomata in $1 \mathrm{~mm}^{2}$ of the upper epidermis

Dust fallout - Stomatal index of the upper epidermis

Significant Correlations,
$(\mathbf{r}), \mathbf{n = 1 0 , p < 0 , 0 5}$
$-0,68$
$+0,75$
$-0,69$
$-0,70$
$+0,74$
$-0,69$
$-0,72$
$+0,70$
$+0,70$
$-0,70$
$-0,76$
$+0,71$
$+0,70$
$-0,81$
$-0,75$

Under the conditions of the waste dump, the dandelion has a fundamentally different system of reliable correlations between the anatomical and morphological characters in comparison with the plants of the control plot (Table 5). This is expressed in an increase in the total number of correlations, and to a greater extent due to positive correlations.

So, in a dandelion, under conditions of a pit hill, close correlations arise between the thickness of the upper and lower epidermis ( +0.84$)$; the thickness of the mesophyll positively correlates with the width of the cells and the number of stomata of the lower epidermis (+0.84, +0.86 , respectively), the thickness of the lower epidermis positively correlates with the length of stomata of the lower epidermis $(+0.81)$ and negatively with the width of stomata of the upper epidermis $(-0.87)$; there is an inverse close relationship between the number of cells of the upper epidermis and the number of cells of the lower epidermis $(-0.89)$ and a direct correlation with the length of the stomata of the lower epidermis $(+0.81)$. The number of cells of the lower epidermis is closely related by feedback with the length of the stomata of the upper 
epidermis (-0.97) and a direct relationship with the stomatal index of the lower epidermis (+0.86). There is a direct positive relationship between the number of stomata of the upper and lower epidermis (+0.82) (Table 5).

Table 5. Correlations between the anatomical indicators of the leaves of the Taraxacum officinale Wigg.

\begin{tabular}{|c|c|c|}
\hline Depending studied traits & $\begin{array}{l}\text { Significant Correlations, } \\
(\mathrm{r}), \mathrm{n}=150, \mathrm{p}<0,05 \\
\text { control }\end{array}$ & experience \\
\hline Leaf thickness-stomata width of the lower epidermis & $-0,83$ & - \\
\hline Thickness of the upper epidermis-Thickness of the lower epidermis & - & $+0,84$ \\
\hline Thickness of the upper epidermis-Mesophyll thickness & $+0,89$ & - \\
\hline Thickness of the upper epidermis-width of the stoma of the upper epidermis & - & $+0,97$ \\
\hline Mesophyll thickness-number of cells in the lower epidermis & $+0,84$ & - \\
\hline Mesophyll thickness-cell width of the lower epidermis & - & $+0,84$ \\
\hline Mesophyll thickness- number of stomata of the lower epidermis & - & $+0,86$ \\
\hline $\begin{array}{l}\text { Thickness of the lower epidermis-width of the stomata of the upper } \\
\text { epidermis }\end{array}$ & - & $-0,87$ \\
\hline $\begin{array}{l}\text { Thickness of the lower epidermis-length of the stomata of the lower } \\
\text { epidermis }\end{array}$ & - & $+0,81$ \\
\hline $\begin{array}{l}\text { Number of cells in the upper epidermis-number of cells in the lower } \\
\text { epidermis }\end{array}$ & - & $-0,89$ \\
\hline $\begin{array}{l}\text { Number of cells of the upper epidermis-number of stomata of the upper } \\
\text { epidermis }\end{array}$ & $-0,94$ & - \\
\hline $\begin{array}{l}\text { Number of cells in the upper epidermis-stomatal index of the lower } \\
\text { epidermis }\end{array}$ & $+0,96$ & - \\
\hline $\begin{array}{l}\text { Number of cells of the upper epidermis-Length of the stomata of the lower } \\
\text { epidermis }\end{array}$ & - & $+0,81$ \\
\hline $\begin{array}{l}\text { Number of stomata of the upper epidermis-stomatal index of the lower } \\
\text { epidermis }\end{array}$ & $+0,96$ & - \\
\hline $\begin{array}{l}\text { Number of stomata of the upper epidermis-number of stomata of the lower } \\
\text { epidermis }\end{array}$ & - & $+0,82$ \\
\hline $\begin{array}{l}\text { Number of cells in the lower epidermis-length of the stomata of the upper } \\
\text { epidermis }\end{array}$ & - & $-0,97$ \\
\hline $\begin{array}{l}\text { Number of cells in the lower epidermis-stomatal index of the lower } \\
\text { epidermis }\end{array}$ & - & $+0,86$ \\
\hline $\begin{array}{l}\text { Stomatal width of the upper epidermis-stomatal index of the upper } \\
\text { epidermis }\end{array}$ & $+0,86$ & - \\
\hline Total correlations: & 7 & 11 \\
\hline$r+/ r-$ & 3,5 & 2,66 \\
\hline
\end{tabular}

Positive correlations are known to control the development of biosystems and arise during periods critical for the organisms. Therefore, a coordinated increase in the number of correlations and more positive between the anatomical parameters of the dandelion leaf can be considered as a specific reaction aimed at survival and a stable existence in the conditions of a rock dump.

\section{Conclusion}

The specific environmental conditions of the Kedrovsky coal mine rock dump cause morphological and anatomical changes in the leaves of Taraxacum officinale Wigg. It was revealed that the responses in the conditions of the waste dump are: at the level of leaf morphology - a decrease in the average leaf area, thickening of lamina, the formation of a trend towards a decrease in the number of leaf rosette; at the level of the anatomical structure - a significant increase in the thickness of the mesophyll, a tendency to a decrease in the thickness of the tissues of the upper and lower epidermis, a decrease in the number of cells in $1 \mathrm{~mm}^{2}$ and an increase in the size of stomata in the tissues of the lower and upper epidermis, a decrease in the number of stomata by $1 \mathrm{~mm}^{2}$, a decrease in the stomatal index on the upper epidermis.

Reliable correlations between the morphological and anatomical parameters of the leaves of Taraxacum officinale Wigg. were established and a comprehensive indicator of atmospheric pollution and dust: leaf area, thickness of the upper and lower epidermis, the number of cells and stomata in $1 \mathrm{~mm}^{2}$ of the lower and upper epidermis negatively correlate with the index of $\mathrm{Cl}$; leaf thickness, mesophyll thickness, length and width of stomata of lower and upper epidermis positively correlate with $\mathrm{Cl}$; the number of stomata is $1 \mathrm{~mm}^{2}$ and the stomatal index of the upper epidermis is inversely related to the amount of dust fallout.

Thus, the experimentally established success rate of the growth of Taraxacum officinale Wigg. in conditions of a rock dump, including a certain correlation of "+» and «-», reliable correlations between the indicators of technogenic pollution of the pit heap and the anatomical and morphological characteristics of the leaves are provided. Under the conditions of a rock dump at Taraxacum officinale Wigg. a fundamentally different system of reliable correlations between anatomical and morphological characters in comparison with plants of the control plot is being formed. This is expressed in an increase in the total number of correlations, and to a greater extent due to positive correlations, which are known to control the development of biosystems and occur during periods critical for the body. A coordinated increase in the number of correlations between the anatomical parameters of the leaf of Taraxacum officinale Wigg., as well as the indicators of atmospheric pollution can be considered as a specific adaptive reaction aimed at survival and stable existence in conditions of a rock dump.

\section{Acknowledgments}

This work was carried out on the state order of the Federal Research Center for Coal and Coal Chemistry SB RAS (Project 0352-2019-0015). 


\section{References}

Akateva, T.G. (2014). The use of bioindication method in assessing the quality of atmospheric air. Modern science agro industrial production: Materials of the International scientific-practical conference dedicated to the 135th anniversary of the first secondary educational institution of the Trans-Urals - the Alexander Real School and the 55th anniversary of the GAU of Northern Zauralie (October 23-24, 2014). Tyumen: GAU of Northern Trans-Urals, 1, 3-6. (in Russian)

Bissing, D.R. (1982). Evolution of leaf architecture in the chaparal species

Fremontodendron californicum ssp. californicum (Sterculiaceae). Amer J Bot, 6 (69), 957-972.

Bykov, A.A., Schastlivtsev, Ye.L., Pushkin, S.G., Klimovich, M.Y.U. (2002). Development and testing of a local model for the deposition of pollutants of industrial origin from the atmosphere onto the underlying surface. Chemistry for Sustainable Development, 5(10), 563-573. Bykov, A.A., Schastlivtsev, Ye.L., Pushkin, S.G., Smirnova, O.V. (2006). Modeling of soil pollution by atmospheric emissions from industrial facilities in a coal-mining region. Polzunovsky Bulletin, 2, 209-217.

Ceulemans, R., Jmpens, J., Lemeur, R., Moermans, R., Samsuddin, Z. (1978). Water movements in the soil-poplar atmosphere system. Oecol Plant, 13(1), 1-12.

Frolov, A.K. (1998). The environment of a big city and the life of plants in it. SPb: Nauka, 328.

Ivanova, L.A. (2014). Adaptive features of leaf structure in plants of different ecological groups. Russian Journal of Ecology, 45(2), 107-115. Krokhmal, I.I. (2015). Functional anatomy and morphology of leaf Campanula sibirica L. Ecology and noospherology, 26(1-2), 54-65.

Lauri P.E., Marceron, A., Normand, F., Anaelle Dambreville., Jean-Luc Regnard. (2014). Soil water deficit decreases xylem conductance efficiency relative to leaf area and mass in the apple. The Journal of Plant Hydraulics, 1(e 0003), 12.

Manakov, Y.U.A. (2012). Restoration of vegetation in technogenic landscapes of Kuzbass, CandSci. Dissertation, Biology. Kemerovo, 374p. ( in Rassian)

Menshakova, M.Y.U., Zhirov, V.K., Khaitbayev, A.KH., Gaynanova, R.I., Kislykh, Ye.Ye. (2008). Variability of the photosynthetic apparatus: boreal and subarctic ecosystems. M Nauka, 117p.

Neverova, O.A., Legoshchina, O.M., Bykov, A.A. (2013). Anatomy of leaves of Betula pendula (Roth) affected by air emissions in Industrial area of kemerovo city. Middle East Journal of Scientific Research, 17(3), 354-358.

Order of the Ministry of Natural Resources of Russia of 06.06.2017 No. 273 On approval of methods for calculating the dispersion of emissions of harmful (polluting) substances in the atmospheric air.

Polovnikova, M.G. (2007). Ecological and physiological features of lawn plants at different stages of ontogenesis in urban environments.

CandSci. Dissertation Abstract, Biology. Nizhny Novgorod, 23.

Programs for ecology and environmental activities [Electronic resource]. Available at: http: //www.lpp.ru (accessed 20.08.2019) (in Russian) Scheepens, J.F., Frey, E.S., Stocklin, J. (2010). Genotypic and environmental variation in specific leaf area in a widespread Alpine plant after transplantation to different altitudes. Oecologia, 164, 141-150.

Zhongqiang, L., Dan, Y. (2009). Factors affecting leaf morphology: A case study of Ranunculus natans C.A. Mey. (Ranunculaceae) in the arid zone of northwest China. Ecol Res, 24, 1323-1333.

Citation: Legoshchina, O.M., Egorova, I.N., Neverova O.A., Bykov, A.A., Maltseva, E.M., Bolshakov V.V. (2019). Features of the morphological and anatomical characteristics of the leaves of Taraxacum officinale Wigg. in conditions of rock dump. Ukrainian Journal of Ecology, 9(3), 78-83.

(cc) B Br whis work is licensed under a Creative Commons Attribution 4.0. License 